\title{
Pengaruh akomodasi pariwisata terhadap pendapatan asli daerah (PAD) provinsi Jawa Timur
}

\author{
Nadila Dwi Adika, Inayati Nuraini Dwiputri* \\ Universitas Negeri Malang, Jl. Semarang No. 5 Malang, Jawa Timur, Indonesia \\ *Penulis korespondensi, Surel: inayati.dwiputri.fe@um.ac.id
}

Paper received: 7-6-2021; revised: 21-6-2021; accepted: 28-6-2021

\begin{abstract}
In the decentralization and regional autonomy era, each region in Indonesia has self authority and obligation to be able to regulate and govern their region. However, performing the authority is costly. The fund is obtained from local government revenue (LCR). There are many factors can increase LCR, for instance, hotel accommodation. Therefore, this study aims to determine the influence of tourism accommodation and other factors which affect Local Government Revenue (LCR). It can be concluded that the number of restaurants, Gross Regional Domestic Product (GRDP), Regional Expenditure has a significant effect to Local Government Revenue (LCR) in accordance with using linear regression analysis method.
\end{abstract}

Keywords: tourism accommodation; GRDP; regional expenditure; LCR

\begin{abstract}
Abstrak
Dalam era desentralisasi dan otonomi daerah saat ini, menjadikan setiap daerah di Indonesia memiliki wewenang serta kewajiban sendiri untuk dapat mengatur dan mengurus sendiri urusan pemerintahan dan kepentingan daerahnya, namun untuk menjalankan kewenangan tersebut dibutuhkan pembiayaan. Pembiayaan tersebut salah satunya berasal dari pendapatan asli daerahnya (PAD). Beberapa faktor yang mempengaruhi peningkatan PAD, salah satunya akomodasi hotel. Penelitian ini bertujuan untuk mengetahui pengaruh akomodasi pariwisata dan faktor-faktor lainnya terhadap PAD. Dengan menggunakan metode analisis regresi linear berganda, hasil penelitian menunjukkan bahwa jumlah rumah makan, Produk Domestik Regional Bruto (PDRB), dan Belanja Daerah berpengaruh signifikan terhadap PAD.
\end{abstract}

Kata kunci: akomodasi pariwisata; PDRB; belanja daerah; PAD

\section{Pendahuluan}

Provinsi Jawa Timur ialah salah satu dari enam provinsi yang terletak di Pulau Jawa. Provinsi ini terbagi menjadi 2 yaitu Jawa Timur daratan serta Kepulauan Madura. Yang mana 90\%merupakan wilayah daratan sedangkan sisanya yaitu sekitar $10 \%$ merupakan wilayah Kepulauan Madura. Luas wilayah Jawa Timur sendiri yaitu sekitar $47.995 \mathrm{~km} 2$. Wilayah tersebut terbagi 29 Kabupaten dan 9 Kota (BPS Provinsi Jawa Timur, 2020)

Adanya desentralisasi serta otonomi daerah seperti yang telah terjadi saat ini menjadikan setiap daerah di Indonesia untuk mengurus pemerintahan dan segala kepentingan yang ada di daerahnya (Undang-Undang Republik Indonesia Nomor 23 Tahun 2014 Tentang Pemerintah Daerah). Namun, Pemerintah Daerah wajib mempersiapkan sebuah rencana pembangunan yang sesuai dengan perencanaan pembangunan nasional (Dwiputri et al., 2019). Selain itu, penting pula dalam menjalankan setiap kegiatan pembangunan dan pemerintahan di daerah otonom untuk mempersiapkan adanya pembiayaan sebagaimana yang dibutuhkan pada setiap kegiatan pembangunan daerah. Untuk itu pemerintah juga diberikan kewenangan dalam mengatur serta mengelola sumber keuangan di daerahnya sehingga dapat 
dipergunakan sebagaimana mestinya dalam kegiatan pembangunan daerah yaitu melalui Pendapatan Asli Daerah (PAD) (Allwati et al., 2019).

Pendapatan Asli Daerah (PAD) dapat diartikan sebagai penerimaan dari berbagai sektor, yaitu yang pertama sektor pajak daerah, yang mana dalam hal ini pemerintah pusat yang dapat menentukan pajak yang dapat dipungut Pemerintah Daerah. Kedua retribusi daerah, ketiga adalah hasil dari perusahaan milik daerah, keempat hasil dari pengelolaan kekayaan dimiliki daerah yang dipisahkan, dan yang kelima adalah lain-lain yang juga merupakan pendapatan asli dari daerah yang sah. Untuk mengoptimalkan dalam penerimaan PAD tersebut tentu sangat diperlukan adanya dukungan serta upaya dari pemerintah daerah dalam rangka mewujudkan kualitas pelayanan public yang lebih baik (Yasin, 2020). Jawa Timur berdasarkan (BPS Provinsi Jawa Timur, 2020) mencatat PAD yang diperoleh setiap tahunnya semakin bertambah besar. Pada tahun 2017 tercatat bahwa realisasi PAD Provinsi Jawa Timur lebih dari 17 Triliun rupiah dan naik hingga diatas 19 Triliun rupiah pada tahun 2019. Nilai PAD yang semakin tinggi setiap tahunnya tentu dapat menjadi indikator bahwa pelaksanaan otonomi daerah di Jawa Timur dapat dikatakan semakin baik. Hal tersebut tentu tidak terjadi tanpa alasan, karena semakin meningkatnya besaran PAD yang diperoleh oleh Provinsi Jawa Timur tentu memiliki banyak faktor yang menjadi pengaruhnya.

Faktor pertama yang menjadi pengaruh adalah akomodasi pariwisata, semakin berkembanganya pariwisata di Indonesia tentu akan mengakibatkan semakin meningkat pula jumlah akomodasi yang tersedia guna menunjang kegiatan pariwisata yang dilakukan oleh wisatawan. Seperti yang dijelaskan dalam (Utami et al., 2019) bahwa akomodasi ini merupakan salah satu dari indikator pengadaan fasilitas guna keperluan pariwisata. Begitu pula dengan Provinsi Jawa Timur, tercatat berdasarkan data Badan Pusat Statistik (BPS) akomodasi yang disediakan dalam hal ini salah satunya adalah hotel/penginapan semakin meningkat jumlahnya. Yang mana pada tahun 2017, BPS mencatat jumlah hotel baik yang berbintang maupun non bintang semakin bertambah yaitu sebanyak 3.369 unit pada tahun 2018 dan meningkat menjadi 4.132 unit pada tahun 2019. Berdasarkan (Sutrisno, 2013) menjelaskan bahwa jumlah hotel yang semakin meningkat dapat diartikan sebagai situasi perkembangan dari adanya fasilitas masyarakat yang semakin banyak dimana setiap perjalanan ke objek pariwisata tentu akan semakin menguntungkan bagi sisi perekonomian apabila wisatawan dapat menginap di Hotel daerah yang dikunjungi.

Faktor kedua adalah jumlah restoran/rumah makan, yang mana seperti halnya jumlah hotel/ penginapan, jumlah restoran/rumah makan ini juga memiliki peran dan pengaruh terhadap PAD. Hal tersebut dapat dilihat dari pendapatan pemerintah dari sektor pajak, sehingga melalui pajak ini yang juga merupakan bagian dari pembentuk PAD menjadikan peningkatan jumlah restoran/rumah makan ini penting untuk Pendapatan Asli Daerah (Suartini \& Utama, 2013). Di Provinsi Jawa Timur pada dasarnya jumlah restoran atau rumah makan mengalami peningkatan yang tidak besar, misalnya pada tahun 2019 sebanyak 4.203, meningkat jika dibandingkan dengan tahun 2018 dengan jumlah rumah makan/restoran sebesar 4.169 (BPS Provinsi Jawa Timur, 2020).

Faktor Ketiga adalah Produk Domestik Regional Bruto atau disebut PDRB, diartikan sebagai nilai dari barang dan jasa yang telah diproduksi oleh penduduk maupun yang bukan penduduk dari negara tersebut namun kegiatan produksinya berada di Negara tersebut. Semakin tinggi PDRB pada suatu daerah, berarti kemampuan masyarakat di daerah tersebut 
dalam membiayai keperluan hidupnya juga semakin baik demikian pula dalam pembiayaan kegiatan di pemerintahannya karena PDRB yang tinggi mengakibatkan penerimaan di daerah tersebut juga akan semakin besar. Dapat disimpulkan pula dengan PDRB yang tinggi dapat terlihat potensi dari daerah untuk dibangun sehingga akan memperoleh PAD yang lebih besar pula (Sari, 2013).

Faktor keempat adalah belanja Daerah, belanja daerah ini merupakan pengeluaran atau bisa disebut belanja yang dilakukan oleh pemerintah di suatu daerah. Belanja pemerintah ini dituangkan dalam Anggaran Pendapatan dan Belanja Daerah. Pengeluaran pemerintah ini dapat digunakan sebagai investasi pemerintah baik untuk memperoleh pendapatan pada masa yang akan datang, maupun pada pemaksimalan pengadaan fasilitas publik dan juga mutu pelayanan (Oktavina, 2012).

Dengan menggunakan keempat faktor tersebut maka akan digunakan metode regresi dengan memakai data sekunder yang berasal dari publikasi baik BPS maupun Kementerian Keuangan Indonesia. Sehingga hasil akhirnya dapat diperoleh faktor yang memiliki dampak positif serta signifikan bagi Pendapatan Asli Daerah, hasil tersebut dapat menjadi pilihan dalam menentukan kebijakan yang akan datang guna meningkatkan PAD di Jawa Timur khususnya maupun Provinsi atau daerah lainnya di Indonesia. Untuk itu dipilihlah judul yaitu "Pengaruh Akomodasi Pariwisata dan Faktor-Faktor Lainnya terhadap Pendapatan Asli Daerah (PAD) Provinsi Jawa Timur".

\subsection{TINJAUAN PUSTAKA}

\subsubsection{Pendapatan Asli Daerah (PAD)}

Menurut (UU Republik Indonesia No. 33 Tahun 2004 Tentang Perimbangan Keuangan Antara Pemerintah Pusat Dan Pemerintah Daerah) PAD diartikan pendapatan suatu daerah melalui kegiatan yang disebut pemungutan sebagaimana pada aturan perundang-undangan. PAD sendiri yang diperoleh melalui pajak, retribusi, serta pendapatan uang sah lainnya akan dipergunakan dalam membiayai setiap kegiatan maupun pembangunan di daerahnya masingmasing. PAD dapat dikatakan sebagai indikator yang menunjukkan keberhasilan setiap daerah dalam menggali setiap potensi yang dimiliki, untuk itu daerah yang memiliki PAD lebih besar

berarti telah berhasil meningkatkan kemandirian daerah tersebut dalam mengambil keputusan dan kebijakan dalam pembangunan daerah (Sari, 2013).

\subsubsection{Akomodasi Pariwisata/Jumlah Hotel}

Akomodasi dapat diartikan sebagai suatu layanan dalam hal ini adalah penginapan namun juga telah disertai dengan kebutuhan penunjang pariwisata lainnya. Usaha penyediaan akomodasi dapat dalam bentuk hotel, pondok wisata, vila, tempat persinggahan, maupun akomodasi lain guna menunjang kegiatan wisata. Sedangkan hotel dapat diartikan sebagai penyediaan akomodasi yang biasanya menggunakan tarif harian yang berbentuk kamar-kamar dan berada pada suatu bangunan dengan dilengkapi pula jasa makan minum, kegiatan hiburan maupun fasilitas penunjang lainnya (BPS Provinsi Jawa Timur, 2020). 


\subsubsection{Produk Domestik Regional Bruto (PDRB)}

Produk Domestik Regional Bruto (PDRB) merupakan bagian dari indikator penting dalam melihat keadaan ekonomi di suatu daerah. Yang mana arti dari PDRB ini adalah jumlah nilai tambah/hasil akhir dari barang yang dihasilkan oleh seluruh unit usaha pada suatu daerah tertentu. Penelitian ini menggunakan data PDRB Atas Dasar Harga Konstan 2010 Menurut Kabupaten/Kota di Provinsi Jawa Timur (miliar rupiah), sebagaimana penelitian Dwiputri, Pradiptyo \& Arsyad (2019).

\subsubsection{Belanja Daerah}

Belanja Daerah dalam (Peraturan Kementerian Dalam Negeri (Permendagri) No. 13 Tahun 2006 Tentang Pedoman Pengelolaan Keuangan Daerah) No. 13 Tahun 2006 Tentang Pedoman Pengelolaan Keuangan Daerah) pasal 31 ayat (1) dijelaskan bahwa belanja daerah ini dikeluarkan untuk dipergunakan dalam hal pembiayaan setiap kegiatan maupun urusan dari pemerintah di tingkat provinsi maupun kabupaten/kota baik untuk urusan wajib, pilihan, dan urusan lainnya yang dilaksanakan bersama oleh pemerintah pusat dan daerah ataupun antar pemerintah daerah sebagaimana dalam perundang-undangan. Belanja daerah telah dikelompokkan menjadi 2, yaitu: belanja tidak langsung dan belanja langsung (Herlina, 2013).

\section{Metode}

Dalam menjalankan penelitian ini, peneliti menggunakan metode penelitian kuantitatif yaitu dengan Regresi linear berganda dengan data sekunder sebagai data penelitian.

\subsection{Deskriptif Kuantitatif}

Menurut Martono (2010) dalam (Islamy, 2019) mendefinisikan penelitian kuantitatif sebagai sebuah penelitian yang dilakukan dengan menggunakan data berupa angka.

\subsection{Regresi Linear Berganda}

Regresi linear berganda merupakan analisis yang digunakan apabila ingin mengetahui bagaimana keadaan/naik turunnya variabel kriterium, bila dua atau lebih (lebih dari satu) variabel prediktor dimanipulasi (Gunawan, 2017). Variabel bebas (independent variable) dalam penelitian ini adalah: Akomodasi hotel, jumlah rumah makan, PDRB, dan Realisasi Belanja Daerah. Dan variabel dependen (dependent variable) yaitu Realisasi Pendapatan Asli Daerah. Data tersebut adalah data-data sekunder yang diperoleh dari dokumen resmi yang dikeluarkan instansi yang terkait.

\section{Hasil dan Pembahasan}

\subsection{Hasil Penelitian}

\subsubsection{Pendapatan Asli Daerah (PAD)}

PAD dapat menunjukkan keberhasilan dari otonomi daerah dalam usahanya menggali potensi untuk meningkatkan sumber-sumber penerimaan. PAD yang semakin tinggi dapat diartikan bahwa daerah tersebut semakin mandiri dalam mengambil keputusan dan kebijakan pembangunan. Pendapatan Asli daerah ini merupakan bentuk penerimaan dari pemerintah daerah guna pembiayaan daerahnya, untuk itu berdasarkan (RPJMD Provinsi Jawa Timur 
2019-2024) Pemerintah Provinsi Jawa Timur berupaya untuk meningkatkan komponen PAD guna menjadi sumber daya bagi daerah agar semakin meningkat, sehingga dapat menjadi pembuktian dari adanya otonomi daerah yang semakin luas dan bertanggung jawab sehingga terwujud pula pembiayaan daerah melalui pendapatan daerah sendiri lebih maksimal.

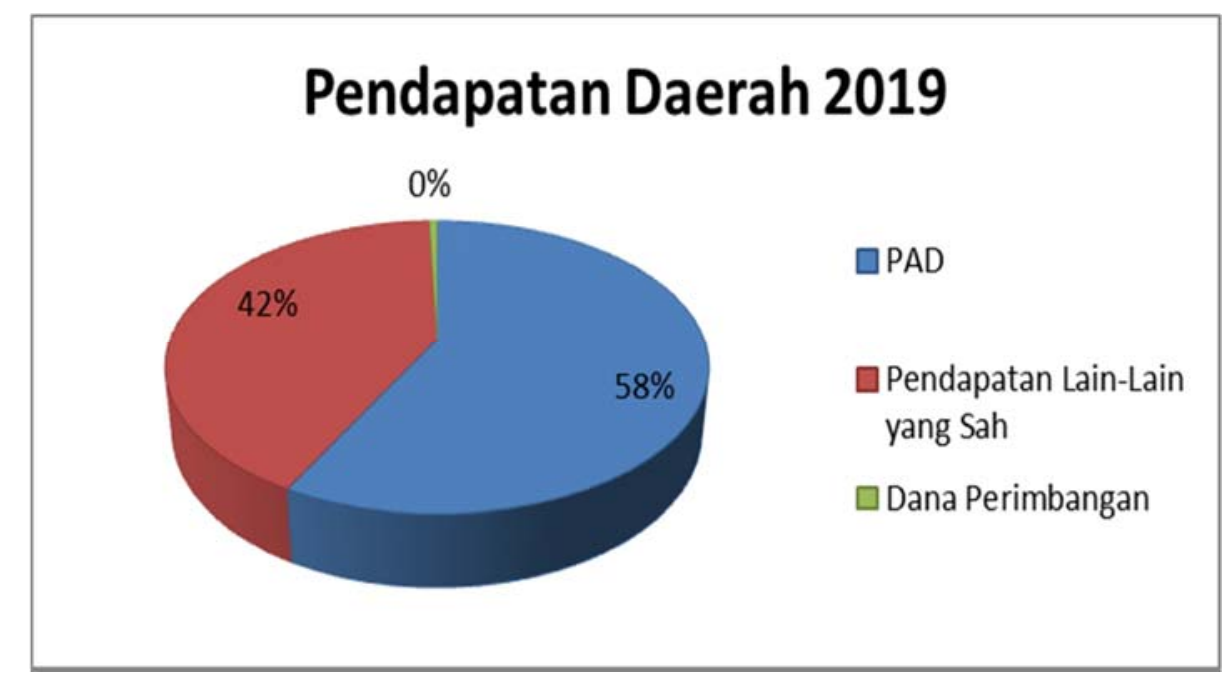

Gambar 1. Realisasi Pendapatan Daerah di Provinsi Jawa Timur 2019 Sumber: (BPS Provinsi Jawa Timur, 2020)

Berdasarkan Gambar 3.1 terlihat bahwa PAD merupakan penyumbang terbesar dalam Pendapatan Daerah dengan nilai 58\% dari pendapatan daerah Provinsi Jawa Timur secara keseluruhan.

\subsubsection{Akomodasi Pariwisata (Hotel)}

Akomodasi pariwisata dijelaskan merupakan pelayanan penginapan yang biasanya dilengkapi pula dengan adanya pelayanan di sektor pariwisata lainnya. Usaha penyediaan akomodasi dapat berupa hotel, persinggahan vila, pondok wisata, karavan, tempat untuk perkemahan dan akomodasi lainnya yang digunakan untuk tujuan pariwisata (BPS Provinsi Jawa Timur, 2020). Sehingga untuk tujuan pengembangan pariwisata yang pada akhirnya akan berpengaruh pada PAD ini menjadikan jumlah akomodasi pariwisata dalam hal ini hotel atau sejenisnya sangat penting. Partum-buhan akomodasi pariwisata di Provinsi Jawa Timur pada tahun 2017 ke 2019 lebih besar jika dibandingkan pada tahun 2015 ke 2017. Sehingga melalui penelitian ini akan dapat dilihat apakah dengan memiliki akomodasi yang lebih banyak ini akan berpengaruh terhadap PAD.

\subsubsection{Jumlah Rumah Makan}

Jumlah rumah makan berdasarkan data yang dipublikasikan oleh Badan Pusat Statistik Provinsi Jawa Timur menunjukkan kenaikan jumlah setiap tahunnya. Kenaikan jumlah tersebut tentu memiliki arti yang positif terhadap penerimaan daerah, khususnya di sektor pajak dan tentunya akan masuk pada PAD dari daerah tersebut. Pada tahun 2019, BPS mencatat jumlah rumah makan/ restoran di Jawa Timur sebanyak 4.203 unit yang naik sebesar lebih dari 1200 unit jika dibandingkan dengan tahun 2015. 


\subsubsection{Produk Domestik Regional Bruto (PDRB)}

PDRB Provinsi Jawa Timur setiap tahunnya memiliki nilai yang semakin tinggi, namun jika dilihat dari pertumbuhannya masih sedikit kecil yaitu berkisar pada 5,5\%. Dimana pada tahun 2019 sendiri pertumbuhan PDRB Provinsi Jawa Timur belum dapat lebih tinggi dari pada yang terjadi pada tahun 2016 walaupun sudah 3 tahun berlalu. Yang berarti bahwa pertumbuhan/persentase peningkatan PDRB di Jawa Timur masih dapat lebih ditingkatkan agar maksimal.

Tabel 1. PDRB di Jawa Timur atas Dasar Harga Konstan 2010 Tahun 2015-2019

\begin{tabular}{ccc}
\hline Tahun & PDRB (dalam Miliar Rupiah) & Pertumbuhan (\%) \\
\hline 2015 & $1.331 .376,10$ & - \\
2016 & $1.405 .563,51$ & 5,57 \\
2017 & $1.482 .299,58$ & 5,46 \\
2018 & $1.563 .769,10$ & 5,50 \\
2019 & $1.650 .143,15$ & 5,52 \\
\hline
\end{tabular}

Sumber: (BPS Provinsi Jawa Timur, 2020)

PDRB Jawa Timur 2019 berdasarkan data BPS merupakan PDRB tertinggi kedua di Indonesia setelah ibu kota DKI Jakarta, yang mana PDRB DKI Jakarta pada tahun 2019 adalah lebih dari Rp. 1838 trilliun.

\subsubsection{Belanja Daerah}

Belanja Daerah digunakan oleh pemerintah daerah dalam hal membiayai pelaksanaan kegiatan ataupun urusan dari pemerintah daerah. Di Provinsi Jawa Timur belanja daerah selalu mengalami peningkatan setiap tahunnya, pada Tahun 2019 total Belanja Daerah Provinsi Jawa Timur mencapai lebih dari Rp. 34 Trilliun. Hal tersebut diperhatikan oleh pemerintah Jawa Timur guna mengimbangi peningkatan belanja daerah dengan meningkatkan pendapatan daerah.

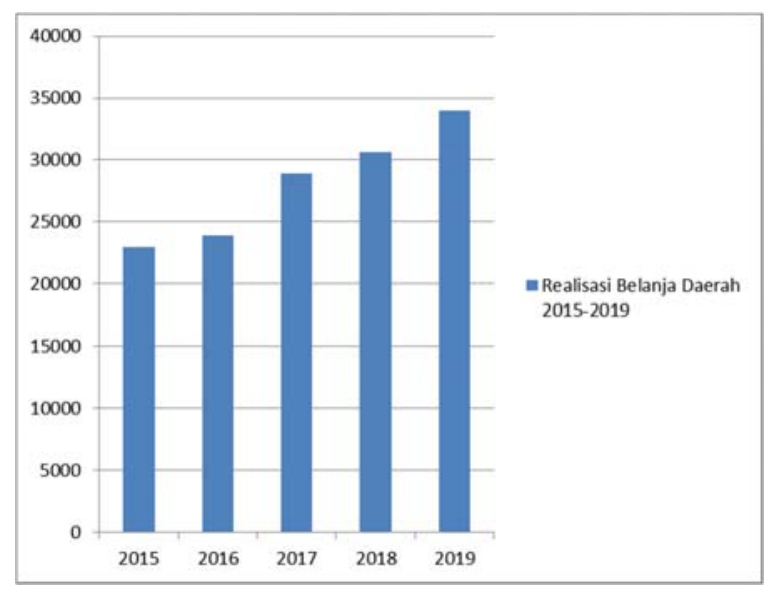

Sumber: (BPS Provinsi Jawa Timur, 2020)

Gambar 2. Realisasi Belanja Daerah Provinsi Jawa Timur 2015-2019 


\subsection{Interpretasi Data Hasil Regresi Linear Berganda}

\subsubsection{Hasil Regresi Data Cross Section}

Berdasarkan menggunakan regresi linear berganda melalui software stata, diperoleh hasil pada Tabel 2. yang akan menjelaskan hasil regresi berganda data cross section.

Tabel 2. Hasil Analisis Regresi Linear Berganda Cross Section

\begin{tabular}{|c|c|}
\hline & (1) \\
\hline VARIABLES & Ln PAD \\
\hline \multirow[t]{2}{*}{ Ln Akomodasi Hotel } & 0.0040 \\
\hline & $(0.0429)$ \\
\hline Ln Jumlah Rumah Makan & $\begin{array}{l}0.1282^{* *} \\
(0.0565)\end{array}$ \\
\hline \multirow[t]{2}{*}{ Ln PDRB } & $0.3816^{* * *}$ \\
\hline & $(0.0929)$ \\
\hline \multirow[t]{2}{*}{ Ln Belanja Daerah } & $0.4335^{* *}$ \\
\hline & $(0.1644)$ \\
\hline \multirow[t]{2}{*}{ Constant } & $-1.8276^{* *}$ \\
\hline & $(0.7714)$ \\
\hline $\mathrm{N}$ & 38 \\
\hline $\mathrm{R}^{2}$ & 0.8596 \\
\hline
\end{tabular}

Analisis regresi linear berganda ini memiliki tujuan guna menguji adanya pengaruh dari empat variabel yaitu Akomodasi Hotel (X1), Jumlah Rumah Makan (X2), PDRB (X3), Belanja Daerah (X5) terhadap Pendapatan Asli Daerah (PAD) (Y). Berdasarkan tabel 2 maka model bentuk dari regresi yang dapat dijabarkan sebagaimana persamaan berikut:

$$
\mathbf{Y}=\mathbf{a}+\mathbf{b}_{1} X_{1}+\mathbf{b}_{2} X_{2}+\mathbf{b}_{3} X_{3}+\mathbf{b}_{4} X_{4}+\mathbf{e}
$$

PAD $=-1.8276+0.0040_{\text {Akomodasi Hotel }}+0.1282_{\text {Jumlah Rumah Makan }}+0.3816_{\text {PDRB }}+$

0.4335 Belanja Daerah 


\subsubsection{Hasil Uji Asumsi Klasik}

\subsubsection{Uji Normalitas}

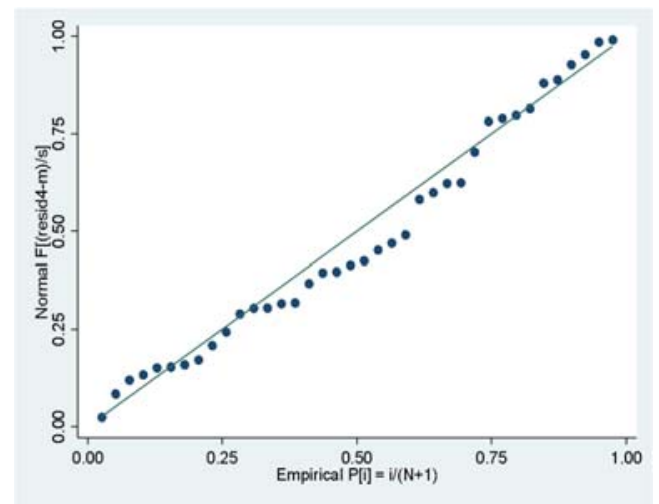

Sumber: STATA, 2020

Gambar 3. Hasil Uji Normalitas

Berdasarkan gambar 3 diatas, dapat diketahui bahwa gambar titik menyebar dan mengikuti di sekitar garis diagonal sehingga dapat disimpulkan bahwa model regresi pada penelitian ini telah memenuhi asumsi uji normalitas sehingga data telah terdistribusi secara normal. Selain menggunakan seperti pada gambar 3, yaitu uji statistik Shapiro Wilk (Swilk).

Tabel 3. Hasil Uji Normalitas Shapiro Wilk

\begin{tabular}{lll}
\hline Variabel & $\mathrm{Z}$ & Prob $>\mathrm{z}$ \\
Resid2 & 0.434 & 0.33200 \\
\hline
\end{tabular}

Sumber: Data diolah, 2020

Dari Tabel 3 uji normalitas terpenuhi karena nilai Prob $>$ z lebih besar jika dibandingkan $\alpha$ sehingga penelitian ini memiliki distribusi normal yaitu $0.33200>0.05$.

\subsubsection{Uji Multikolinearitas}

Pengujian multikolinearitas memiliki tujuan mengetahui adanya korelasi antar variabel bebas yang digunakan dalam model regresi di penelitian ini dengan menggunakan Tollerance dan Variance Inflation Factor (VIF) Tabel 4 akan menjelaskan hasil uji multikolinearitas menggunakan software STATA.

\section{Tabel 4. Hasil Uji Multikolinearitas}

\begin{tabular}{lll}
\hline Variabel & VIF & $1 /$ VIF \\
Ln PDRB & 3.92 & 0.25504 \\
& & 7 \\
Ln Belanja Daerah & 3.07 & 0.32591 \\
& & 9
\end{tabular}


Jurnal Ekonomi, Bisnis dan Pendidikan, 1(6), 2021, 600-614

\begin{tabular}{lll}
\hline $\begin{array}{l}\text { Ln Jumlah Rumah } \\
\text { Makan }\end{array}$ & 1.71 & $\begin{array}{l}0.58415 \\
2\end{array}$ \\
Ln Akomodasi Hotel & 1.45 & $\begin{array}{l}0.68902 \\
2\end{array}$ \\
& & \\
Mean VIF & 2.54 &
\end{tabular}

Sumber: Data diolah, 2020

Dari tabel 4 diketahui setiap variabel independen dakam penelitian ini memiliki nilai VIF yang kurang dari 10. Yang berarti gejala multikolinearitas antar variabel bebas dalam penelitian ini tidak terjadi.

\subsubsection{Uji Heterokedastisitas}

Tabel 5 merupakan hasil analisis pengujian heterokedastisitas menggunakan software STATA.

Tabel 5. Hasil Uji Heterokedastisitas

\begin{tabular}{cc}
\hline $\mathrm{Chi}^{2}(1)$ & 0.71 \\
Prob $>\mathrm{Chi}^{2}$ & 0.3988 \\
\hline \multicolumn{2}{l}{ Sumber: Data diolah, 2020 }
\end{tabular}

Dari tabel 5 terbaca bahwa Non-Heterokedastisitas terpenuhi karena Prob $>\mathrm{Chi}^{2}$ (0.3988) lebih dari nilai $\alpha(0.05)$. Selain dari tabel diatas, heterokedastisitas juga dapat dilihat dari scatterplot. Uji heterokedastisitas dari scatterplot dengan menggunakan software STATA dapat dilihat pada Gambar 4.

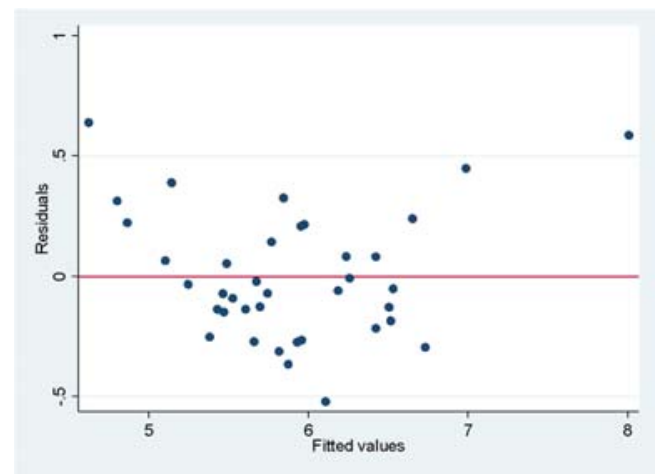

Sumber: STATA, 2020

Gambar 4. Scatterplot Heterokedastisitas

Dari gambar diatas terlihat bahwa titik yang merupakan representasi dari variabel bebas tergambar menyebar acak dan tidak berbentuk pola yang teratur. Maka data tersebut telah menyimpulkan bahwa tidak adanya gejala heterokedastisitas, sehingga model regresi dengan menggunakan 4 variabel bebas tersebut layak digunakan dalam memprediksi PAD. 


\subsubsection{Hasil Uji Statistik}

\subsubsection{Uji Signifikansi Individual (Uji t)}

Uji t dilakukan guna mengetahui apakah setiap variabel bebas dalam penelitian ini memiliki pengaruh variabel terikat. Nilai probabilitas t-hitung dapat menjadi parameter yang dapat digunakan untuk mengetahui pengaruh dari tiap variabel bebas, yang mana probabilitas t-hitung yang lebih kecil dari nilai alpha $(\alpha)$ satu persen, lima persen, maupun sepuluh persen berarti bahwa variabel bebas tersebut berpengaruh terhadap variabel terikat Selain cara diatas dapat juga dilihat melalui t-hitung serta t-tabel. Hal ini dapat dilakukan dengan ketentuan apabila t-hitung bernilai lebih besar dari t-tabel maka terdapat pengaruh signifikan dan sebaliknya apabila t-hitung lebih kecil/kurang dari t-tabel maka tidak berpengaruh signifikan.

Nilai t-tabel dapat ditentukan dengan rumus berikut:

$$
\begin{aligned}
\mathrm{t}-\text { tabel } & =\mathrm{t}(\alpha / 2, \mathrm{n}-\mathrm{k}-1) \\
& =\mathrm{t}(0,05 / 2,38-4-1) \\
& =\mathrm{t}(0,025,33) \\
& =2.024
\end{aligned}
$$

Dimana $\alpha$ adalah tingkat kepercayaan $95 \%$ yaitu 0.05 atau signifikan pada 5\%. Sehingga diperoleh nilai t-tabel sebesar 2.024, nilai tersebut dapat dilihat pada t-tabel dengan kolom 0.025 dan baris ke-33.

Tabel 6. Hasil Uji t

\begin{tabular}{cccc}
\hline Variabel & t-hitung & t-tabel & Kesimpulan \\
\hline Ln Akomodasi Hotel & 0.09 & 2.024 & Tidak Signifikan \\
Ln Jumlah Rumah Makan & 2.27 & 2.024 & Signifikan \\
Ln PDRB & 4.11 & 2.024 & Signifikan \\
Ln Belanja Daerah & 2.64 & 2.024 & Signifikan \\
\hline
\end{tabular}

Sumber: Data diolah, 2020

$\mathrm{H}_{0}$ : Akomodasi Hotel, Jumlah Rumah Makan, PDRB, dan Belanja Daerah tidak mempengaruhi PAD secara signifikan.

$\mathrm{H}_{1}$ : Akomodasi Hotel, Jumlah Rumah Makan, PDRB, dan Belanja Daerah mempengaruhi PAD secara signifikan.

Dari Tabel 6 maka dapat diambil kesimpulan bahwa:

Terdapat pengaruh positif serta tidak signifikan antara variabel Akomodasi Hotel terhadap PAD dikarenakan jumlah t-hitung yaitu 0.09 yang artinya lebih besar dibandingkan t-tabel yaitu 2.024 .

Terdapat pengaruh yang positif serta signifikan antara variabel Jumlah Rumah Makan terhadap PAD. Hal ini terjadi karena jumlah t-hitung yaitu 2.27 lebih kecil dari t-tabel yaitu 2.024 . 
Terdapat pengaruh positif serta signifikan antara variabel PDRB terhadap PAD. Dikarenakan jumlah t-hitung sebesar 4.11 lebih kecil dibandingkan t-tabel yaitu 2.024

Terdapat pengaruh positif serta signifikan antara variabel Belanja Daerah terhadap PAD. Dikarenakan t-hitung sebesar 2.64 lebih besar apabila dibandingkan t-tabel yaitu 2.024.

\subsubsection{Uji Signifikan Simultan (Uji F)}

Uji F dilakukan dalam rangka mengetahui variabel bebas dapat mempengaruhi variabel terikat secara simultan. Uji ini dilakukan dengan ketentuan apabila F-hitung lebih dari F-tabel, maka variabel bebas mempengaruhi variabel terikat. Sebaliknya, apabila F-hitung kurang dari F-tabel, maka variabel bebas tidak mempengaruhi variabel terikat. $\mathrm{F}$ tabel pada penelitian ini dapat dihitung dengan rumus:

$$
\begin{aligned}
\mathrm{F} \text { table } & =\mathrm{F}(\mathrm{k}, \mathrm{n}-\mathrm{k}) \\
& =\mathrm{F}(4,38-4) \\
& =\mathrm{F}(4,34) \\
& =2.65
\end{aligned}
$$

Dimana $\mathrm{k} \rightarrow$ jumlah variabel bebas dan $\mathrm{n} \rightarrow$ jumlah sampel dalam penelitian. Berdasarkan rumus diatas diperoleh $\mathrm{F}$ tabel pada kolom ke-4 dan baris ke-34.

Tabel 7. Hasil Uji F

\begin{tabular}{ll}
\hline F-hitung & F-tabel \\
\hline $\mathbf{5 0 . 5 1}$ & 2.65 \\
\hline Sumber: Data diolah, 2020 &
\end{tabular}

Dapat terlihat pada tabel 7, bahwa nilai dari F-hitung lebih besar apabila dibandingkan F-tabel dimana 50.51 > 2.65. Sehingga berdasarkan hal tersebut dapat diartikan bahwa dengan p-value (alpha $=5 \%$ maka tolak $\mathrm{H}_{0}$ pada tingkat signifikansi $=5 \%$ ), artinya pada tingkat signifikansi sebesar 5\% variabel bebas (Akomodasi Hotel, Jumlah Rumah Makan, PDRB, dan Belanja Daerah) secara simultan berpengaruh signifikan terhadap variabel bebas yaitu PAD.

\subsubsection{Koefisien Determinasi (R2)}

Koefisien determinasi digunakan untuk mengukur besarnya pengaruh variabel bebas secara keseluruhan terhadap variabel terikat. Nilai $\mathrm{R}^{2}$ yang diperoleh untuk PAD adalah sebesar 0.8596. Artinya variabel independen Akomodasi Hotel, Jumlah Rumah Makan, PDRB, Jumlah Penduduk dan Belanja Daerah mampu menjelaskan variabel dependen PAD sebesar $85,96 \%$. Sementara $14,04 \%$ sisanya merupakan variabel lain yang tidak termasuk variabel bebas dalam penelitian ini. 


\subsection{Pengaruh Akomodasi Hotel, Jumlah Rumah Sakit, PDRB, dan Belanja Daerah terhadap PAD Provinsi Jawa Timur}

\subsubsection{Pengaruh Akomodasi Hotel terhadap PAD}

Berdasarkan regresi dan analisis data yang dilakukan diatas, diperoleh hasil bahwa akomodasi hotel berpengaruh positif serta tidak signifikan terhadap PAD di Provinsi Jawa Timur. Koefisien variabel akomodasi hotel sebesar 0.003951 dengan probabilitas 0.927 menjelaskan bahwa setiap peningkatan satu-satuan akomodasi hotel maka dapat menaikkan PAD sebesar 0.003951 satu-satuan. Yang artinya jika akomodasi pariwisata mengalami peningkatan maka PAD akan meningkat karena memiliki pengaruh yang positif. Sehingga semakin meningkatnya Akomodasi Pariwisata maka akan membuat PAD juga semakin meningkat. Namun peningkatan tersebut tidak signifikan terhadap PAD terbukti dengan nilai $\mathrm{p}$ value nya yang sebesar $0.927>0.05$ (alpha).

Berdasarkan data BPS jumlah akomodasi hotel setiap tahunnya meningkat, sehingga berdasarkan analisis data yang telah dilakukan dan memperoleh hasil koefisien yang positif menjadikan peningkatan dari akomodasi pariwisata tersebut akan berpengaruh positif pula terhadap peningkatan PAD di Provinsi Jawa Timur, walaupun dengan nilai yang tidak signifikan. Dalam penelitian (Sutrisno, 2013) diperoleh kesimpulan bahwa jumlah hotel memiliki pengaruh yang signifikan terhadap retribusi pendapatan di sektor pariwisata pada kabupaten ataupun kota di Jawa Tengah dengan nilai koefisien sebesar 53776,97. Yang mana seperti dijelaskan sebelumnya bahwa retribusi di sektor pariwisata merupakan salah satu bentuk penerimaan dari PAD. Yang mana hasil dari penelitian tersebut sama-sama berpengaruh positif namun perbedaannya terjadi pada signifitasnya.

\subsubsection{Pengaruh Jumlah Rumah Makanterhadap PAD}

Berdasarkan regresi dan analisis data yang dilakukan diatas, diperoleh hasil bahwa jumlah rumah makan berpengaruh positif serta signifikan terhadap PAD di Provinsi Jawa Timur. Koefisien variabel jumlah rumah makan sebesar 0.1281706 dengan probabilitas 0.030 menjelaskan bahwa setiap peningkatan satu-satuan akomodasi hotel maka dapat menaikkan PAD sebesar 0.1281706 satu-satuan. Hal ini berarti jika jumlah rumah makan mengalami peningkatan maka PAD akan meningkat karena memiliki pengaruh yang positif. Sehingga semakin peningkatan dari jumlah rumah makan maka akan membuat PAD semakin meningkat pula.

Berdasarkan data BPS jumlah rumah makan setiap tahunnya meningkat, sehingga peningkatan dari jumlah rumah makan di Provinsi Jawa Timur tersebut akan berpengaruh positif pula terhadap peningkatan PAD di Provinsi Jawa Timur, untuk itu telah menjadi tugas dari pemerintah Jawa Timur untuk mengembangkan dan menarik masyarakat maupun investor agar dapat menambah jumlah rumah makan sehingga penerimaan PAD Provinsi Jawa Timur juga akan semakin meningkat. Karena sama seperti halnya akomodasi hotel, bahwa rumah makan juga akan menambah PAD baik melalui pajak maupun retribusi. Pernyataan tersebut sebagaimana yang dijelaskan pada penelitian (Suartini \& Utama, 2013) bahwa perolehan dari sektor pajak restoran merupakan salah satu variabel yang memiliki pengaruh positif serta signifikan terhadap variabel bebas yaitu (PAD) di Kabupaten Gianyar. 


\subsubsection{Pengaruh PDRB terhadap PAD}

Berdasarkan regresi dan analisis data yang dilakukan diatas, diperoleh hasil bahwa PDRB berpengaruh positif serta signifikan terhadap PAD di Jawa Timur. Koefisien variabel PDRB sebesar 0.3815818 dengan probabilitas 0.000 menjelaskan bahwa setiap adanya PDRB yang naik satu-satuan maka akan menaikkan pula PAD sebesar 0.3815818 satu-satuan. Hal ini diartikan ketika PDRB mengalami kenaikan maka PAD akan ikut meningkat pula. Sehingga tingginya PDRB ikut pula menaikkan PAD.

Berdasarkan BPS PDRB Provinsi Jawa Timur setiap tahunnya meningkat dan memiliki nilai tertinggi kedua se Indonesia, sehingga berdasarkan analisis data yang dilakukan sebelumnya dan diperoleh hasil koefisien yang positif serta signifikan menjadikan peningkatan dari PDRB di Provinsi Jawa Timur tersebut akan berpengaruh positif pula terhadap peningkatan PAD. Hasil tersebut sependapat dengan hasil penelitian (Sutrisno, 2013), dimana dalam penelitian tersebut diperoleh hasil bahwa PDRB berpengaruh signifikan dalam peningkatan pendapatan retribusi yang secara otomatis juga berpengaruh terhadap PAD dengan nilai koefisien sebesar 0,670079. Namun pendapat yang berbeda terlihat pada hasil penelitian (Allwati et al., 2019), yang menyatakan PDRB Kepulauan Selayar berpengaruh positif namun tidak signifikan terhadap PAD Kepulauan Selayar.

\subsubsection{Pengaruh Belanja Daerah terhadap PAD}

Berdasarkan regresi dan analisis data yang dilakukan diatas, diperoleh hasil bahwa Belanja daerah berpengaruh positif serta signifikan terhadap PAD di Jawa Timur. Koefisien variabel belanja daerah sebesar 0.4334914 dengan probabilitas 0.013 menjelaskan bahwa setiap peningkatan satu-satuan belanja daerah maka dapat menaikkan PAD sebesar 0.4334914. yang diartikan apabila terjadi peningkatan pada belanja daerah maka hal yang sama yaitu peningkatan juga akan terjadi pada PAD. Sehingga semakin tinggi Belanja daerah maka PAD akan semakin tinggi.

Berdasarkan data BPS Belanja Daerah Provinsi Jawa Timur setiap tahunnya meningkat, sehingga berdasarkan analisis data yang telah dilakukan dan memperoleh hasil koefisien yang positif serta signifikan menjadikan peningkatan belanja daerah di Jawa Timur tersebut akan berpengaruh positif pula terhadap peningkatan PAD di Provinsi Jawa Timur. Karena bagaimanapun juga belanja daerah akan terjadi sesuai dengan pendapatan yang diperoleh, sehingga belanja daerah yang semakin tinggi dikarenakan Jawa Timur juga memperoleh pendapatan yang lebih tinggi/besar pula. Hasil penelitian ini sesuai dengan penelitian oleh (Oktavina, 2012), yang mana berdasarkan analisis pada penelitian yang telah dilakukan dalam artikel tersebut menjelaskan bahwa belanja daerah memiliki koefisien positif serta signifikan terhadap PAD.

\subsubsection{Pengaruh Akomodasi Pariwisata, Jumlah Rumah Makan, PDRB, dan Belanja Daerah terhadap PAD}

Berdasarkan hasil uji diatas, dapat dilihat bahwa nilai F-hitung lebih besar dibandingkan F-tabel dimana 50.51 > 2.65. Sehingga berdasarkan hal tersebut dapat diartikan bahwa dengan p-value (alpha $=5 \%$ maka tolak $\mathrm{H}_{0}$ pada tingkat signifikansi $=5 \%$ ), artinya pada tingkat signifikansi sebesar 5\% variabel bebas (Akomodasi Hotel, Jumlah Rumah Makan, PDRB, dan

Belanja Daerah) secara bersama-sama berpengaruh secara signifikan terhadap variabel terikat 
yaitu PAD di Provinsi Jawa Timur. Sehingga sangat penting untuk pemerintah Provinsi Jawa Timur dalam memaksimalkan PAD melalui Akomodasi Pariwisata, Jumlah Rumah Makan, PDRB, dan Belanja Daerahnya.

\section{Simpulan}

Adanya era desentralisasi dan otonomi daerah menjadikan pemerintah daerah memiliki wewenang mengatur daerahnya masing-masing. Untuk itu setiap pemerintah daerah berkewajiban dalam mengelola sumber daya serta potensi daerahnya agar dapat menghasilkan sumbangan Pendapatan Asli Daerah guna membangun daerahnya. Nilai PAD yang semakin tinggi setiap tahunnya tentu dapat menjadi indikator bahwa pelaksanaan otonomi daerah di Jawa Timur dapat dikatakan semakin baik. Hal tersebut tentu tidak terjadi tanpa alasan, karena semakin meningkatnya besaran PAD yang diperoleh oleh Provinsi Jawa Timur tentu dipengaruhi oleh banyak faktor, yaitu: akomodasi pariwisata/hotel, jumlah restoran/ rumah makan, PDRB dan belanja Daerah.

Melalui penelitian yang telah dilakukan, maka diperoleh hasil:

Variabel Akomodasi Pariwisata berpengaruh positif dengan koefisien 0.003951tetapi tidak signifikan ( $\mathrm{p}$ value $>$ alpha) terhadap PAD Provinsi Jawa Timur.

Variabel Jumlah Rumah Makan berpengaruh positif dengan koefisien 0.1281706 dan signifikan (p value < alpha) terhadap PAD Provinsi Jawa Timur.

Variabel PDRB berpengaruh positif dengan koefisien 0.3815818 dan signifikan terhadap PAD signifikan ( $p$ value $<$ alpha) Provinsi Jawa Timur.

Variabel Pengeluaran Daerah berpengaruh positif dengan koefisien 0.4334914 dan signifikan $\mathrm{p}$ value $<$ alpha) terhadap PAD Provinsi Jawa Timur.

Uji F diperoleh dari nilai F-hitung yang lebih besar dibandingkan F-tabel dimana 50.51 $>2.65$, artinya pada tingkat signifikansi 5\% variabel bebas (Akomodasi Hotel, Jumlah Rumah Makan, PDRB, dan Belanja Daerah) secara simultan memiliki pengaruh serta signifikan terhadap variabel terikat PAD.

Nilai Koefisien Determinasi (R2) 0.8596, artinya variabel independen Akomodasi Hotel, Jumlah Rumah Makan, PDRB, Jumlah Penduduk dan Belanja Daerah mampu menjelaskan variabel dependen PAD sebesar 85,96\%.

\section{Daftar Rujukan}

Allwati, Naidah, \& Adziem, F. (2019). Faktor Faktor yang Mempengaruhi Pendapatan Asli Daerah Kabupaten Kepulauan Selayar Provinsi Sulawesi Selatan. Balance: Jurnal Ekonomi, 15(1), 25-33. https://journal.unismuh.ac.id/index.php/jeb/article/view/2148

BPS Provinsi Jawa Timur. (2020). Provinsi Jawa Timur dalam Angka 2020. https://jatim.bps.go.id/publication/2020/05/19/6225e5df323aa13d4fb1e4f4/provinsi-jawa-timurdalam-angka-2020.html

Dwiputri, I.N., Pradiptyo, R., \& Arsyad, L. (2019). "Corruption and Capital Growth: Identification of Bribery by the Firm", International Journal of Economics and Management 13(2): 467-479. http://www.ijem.upm.edu.my/vol13no2/15)\%20Corruption\%20and\%20Capital\%20Growth.pdf.

Dwiputri, I. N., Kusufi, M. S., \& Allo, A. G. (2019). Projections of Regional Macroeconomic Conditions using the Univariate Forecasting Method. Economics Development Analysis Journal, 8(3), 329-342. https://doi.org/10.15294/edaj.v8i3.30188 
Gunawan, I. (2017). Pengantar Statistika Inferensial (2nd ed.). PT Raja Grafindo Persada.

Herlina, E. (2013). Faktor-Faktor Yang Mempengaruhi Belanja Daerah Serta Dampaknya Terhadap Produk Domestik Regional Bruto Kabupaten Berau. Journal of Innovation in Business and Economics, 4(1), 2544. https://doi.org/10.22219/jibe.vol4.no1.25-44

INDONESIA, P. R. (2014). Undang-Undang Republik Indonesia Nomor 23 Tahun 2014 tentang Pemerintahan Daerah.

Indonesia, R. (2004). Undang-Undang Republik Indonesia Nomor 33 tahun 2004 tentang. Perimbangan Keuangan antara Pemerintah Pusat dan Pemerintah Daerah.

Islamy, N. (2019). Analisis Sektor Potensial, Dapatkah Pariwisata Menjadi Lokomotif Baru Ekonomi Nusa Tenggara Barat? Journal of Indonesian Tourism, Hospitality and Recreation, 2(1), 1-10. https://ejournal.upi.edu/index.php/Jithor/article/view/16426/9209

Nomor, P. M. D. N. (13). Tahun 2006 tentang Pedoman Pengelolaan Keuangan Daerah.

Oktavina, D. (2012). Analisis Pendapatan Asli Daerah dan Faktor-Faktor yang Mempengaruhinya Dalam Rangka Otonomi Daerah : Pendekatan Error Correction Model. Jurnal Ekonomi Pembangunan, 10(2), 114. http://ejournal.umm.ac.id/index.php/jep/article/view/3720

RPJMD Provinsi Jawa Timur (2019-2024). No Title. http://jatimprov.go.id/ppid/uploads/berkasppid/RPJMD Prov. Jatim 2019 - 2024.pdf

Sari, P. L. P. (2013). Analisis Variabel-Variabel Yang Mempengaruhi Pendapatan Asli Daerah (PAD_Provinsi Bali. Jurnal Ilmiah Dan Akuntansi Dan Humanika JINAH, 2(2), 715-737. https://ejournal.undiksha.ac.id/index.php/JJA/article/view/1678

Suartini, N. N., \& Utama, M. S. (2013). Pengaruh Jumlah Kunjungan Wisatawan, Pajak Hiburan, Pajak Hotel Dan Restoran Terhadap Pendapatan Asli Daerah Di Kabupaten Gianyar. E-Jurnal Ekonomi Dan Bisnis Universitas Udayana, 2(3), 175-189. https://ocs.unud.ac.id/index.php/EEB/article/view/4941

Sutrisno, D. C. (2013). Pengaruh Jumlah Obyek Wisata, Jumlah Hotel, Dan Pdrb Terhadap Retribusi Pariwisata Kabupaten / Kota Di Jawa Tengah. Economics Development Analysis Journal, 2(4), 435-445. https://doi.org/10.15294/edaj.v2i4.3211

Utami, T., Nanang, W., \& Christianingrum. (2019). Analisis Persepsi Pengunjung terhadap Fasilitas, Promosi dan Daya Tarik Wisata di Pantai Pasir Padi Pangkalpinang. Jurnal Pariwisata Pesona, 04(2), 149-157. http://jurnal.unmer.ac.id/index.php/jpp/article/view/3385

Yasin, M. (2020). Analisis Pendapatan Asli Daerah dan Belanja Pembangunan terhadap Pertumbuhan Ekonomi di Kabupaten/Kota Jawa Timur. COSTING:Journal of Economic, Business and Accounting, 3(2), 465-472. https://journal.ipm2kpe.or.id/index.php/COSTING/article/view/1161 